\title{
НАДМІРНЕ СПОЖИВАННЯ ЦУКРУ ТА ЦУКРОВИЙ ДІАБЕТ У ДИТЯЧОМУ ВІЦІ
}

\author{
К. О. Надточий \\ ДВНЗ «Тернопільський державний медичний університет \\ імені І. Я. Горбачевського МОз Украӥни"
}

У статті проаналізовано взаємозв'язок між споживанням доданих цукрів та проблемою цукрового діабету в дітей.

\section{EXCESSIVE CONSUMPTION OF SUGAR AND DIABETES MELLITUS IN CHILDREN}

\section{K. O. Nadtochiy}

\section{Horbachevsky Ternopil State Medical University}

The article analyzes the relationship between the use of added sugars and the problem of diabetes mellitus in children.

Вступ. Цукровий діабет є хронічним захворюванням ендокринної системи, що з'являється через дефіцит інсуліну - особливого гормону підшлункової залози. Призначення інсуліну полягає в тому, щоб забезпечувати надходження в усі клітини людського організму глюкози. Підшлункова залоза у здорової людини виробляє гормон інсулін, він, в свою чергу, приносить розчинену в крові глюкозу всередину клітин. При розвитку цукрового діабету глюкоза самостійно не може проникнути в клітину і змушена залишатися в крові, опиняючись непотрібним елементом [1].

При цьому глюкоза є основним джерелом харчування для організму. Потрапляючи в організм з їжею, вона трансформується всередині клітини в чисту енергію, дозволяє організму повноцінно працювати. Проникнути всередину клітини глюкоза може тільки за допомогою гормону інсуліну. Якщо інсуліну в організмі недостатньо - цукор, тобто глюкоза, залишається в крові. Від цього кров стає більш густою і не здатною швидко переносити кисень і поживні речовини для клітин. Стінки судин для поживних речовин стають непроникними, втрачають свою еластичність. Цукровий діабет у дітей супроводжується порушенням всіх без винятку видів обміну речовин в організмі: вуглеводного, білкового, жирового, мінерального та водно-сольового обміну. Звідси й численні ускладнення цукрового діабету, які є серйозними і досить часто небезпечними для життя [1].

(с) К. О. Надточий, 2018
Існує два типи діабету, які мають істотні відмінності, як з точки зору клінічного розвитку, патогенезу та етіології, так і з точки зору підтримки та лікування.

Перший тип діабету має автоімунну природу і викликаний дефіцитом інсуліну: підшлункова залоза виробляє його недостатньо або зовсім не виробляє, i, як наслідок, підвищується рівень цукру в крові. У такому випадку завжди потрібна інсулінотерапія - щоденні ін'єкції інсуліну, що вводять у строго певній кількості. При діабеті другого типу інсулін виробляється в достатній кількості, а трапляється і більше необхідної норми. Однак гормон виявляється практично недоступним для тканин, оскільки, з тих чи інших причин, вони втрачають чутливість до нього, не розпізнають інсулін.

Другий тип - це найчастіша форма (₹80\%), яка зумовлена поступовим порушенням секреції інсуліну за умов інсулінорезистентності. Може бути генетично зумовленим (полігенне успадкування), однак ключову роль відіграють такі фактори середовища, як ожиріння, особливо абдомінальне, низька фізична активність. Надлишок вільних жирних кислот, які утворюються жировою тканиною, зумовлює «ліпотоксичність» - збільшене окиснення жирів призводить до гальмування гліколізу в м'язах, а у печінці - до посилення глюконеогенезу, що вимагає компенсаційної секреції інсуліну $\beta$-клітинами та може спричинити поступове виснаження їх резерву і порушення метаболізму глюкози [2]. 
До недавнього часу найпоширенішим типом діабету в дітей і підлітків був тип 1, який ще називали підлітковим діабетом. На сьогодні діабет 2 типу, який раніше називали діабетом дорослих, все частіше спостерігають серед дітей та підлітків із надлишковою масою та ожирінням [2].

Основна частина. Вуглеводи $\epsilon$ потрібним та незамінним компонентом добового раціону людини, оскільки забезпечують 25-65 \% усіх калорій. Вуглеводи бувають простими (глюкоза, фруктоза, лактоза, галактоза, сахароза, мальтоза) та складними (крохмаль, клітковина). Прості вуглеводи дуже швидко підвищують рівень цукру в крові (глюкоза та сахароза), тому їх кількість потрібно обмежувати при цукровому діабеті. Водночас, низька фізична активність належить до факторів, які посилюють патологічні зміни при цукровому діабеті [3].

Надмірне споживання простих вуглеводів, цукрів, а також калорійна їжа збільшують ризик ожиріння, цукрового діабету, захворювань серця і судин, сприяють формуванню запального фону в організмі та старінню шкіри. Солодка їжа викликає сильні коливання цукру в крові. Рівень глюкози у крові має бути сталим. Коли рівень глюкози в крові збільшується, виділяється гормон інсулін, і тоді глюкоза залишає кровотік та відкладається в печінці, м'язах та жировій тканині у вигляді запасів - глікогену та жиру. Інтенсивне фізичне навантаження, активна робота м'язів до чи після споживання солодкого змушують м'язи поглинати весь цукор, а тому в жирову тканину його потрапляє значно менше. Стрімке зниження рівня глюкози під дією інсуліну відчувається як голод і нестримне прагнення щось з'істи чи випити солодкого напою [4].

Коли розвивається цукровий діабет у дітей, порушується не лише процес перетворення цукру в глікоген, але й засвоєння глюкози в тканинах. Тому як енергетичний матеріал організм використовує жир, що є причиною активізації ліполізу вісцерального жиру і надходженню в кровотік великої кількості вільних жирних кислот, які, в свою чергу, посилюють процеси інсулінорезистентності.

Першими клінічними ознаками цукрового діабету в дитини є посилена спрага, часте сечовипускання, втрата маси, млявість, відчуття голоду. При цьому дитина просить багато пити, що пояснюється втратою рідини з тканин й клітин організму і появою ознак зневоднення. Водночас велика кількість рідини виводиться з організму, тому діти дуже часто «бігають» в туалет або починають мочитись у ліжко, і якщо такого не траплялося раніше, то найімовірніше, це ознака цукрового діабету. Ще однією ознакою є відсутність позитивної динаміки маси, оскільки втрачається здатність організму отримувати енергію і калорії з глюкози, а їх нестача поповнюється за рахунок жирів. Зміна джерела енергії організмом призводить до зниження життєвої активності, млявості, сонливості дитини та відчуття невгамовного голоду [5].

Клінічні ознаки цукрового діабету в дитини можуть розвинутися в будь-якому віці. На практиці спостерігають два піки маніфестації цукрового діабету в дитячому віці - 5-8 років та пубертатний вік, це періоди посиленого зростання та інтенсивного метаболізму. у більшості випадків розвиток інсулінозалежного цукрового діабету в дітей пов'язаний з вірусною інфекцією: епідемічний паротит, кір, ГРВІ, ентеровірусна інфекція, ротавірусна інфекція, вірусний гепатит тощо.

Основні симптоми цукрового діабету в дітей - це:

1. Поліурія (надмірне виділення сечі) - найчастіше найперша ознака діабету. Вона зумовлена глюкозою, яка розчинена в сечі, і перешкоджає зворотному всмоктуванню води на рівні нирок, з первинної сечі.

2. Полідипсія (сильна, невгамовна спрага) - наслідок посиленої втрати рідини з сечею.

3. Поліфагія («вовчий» апетит) - ознаки ожиріння або, навпаки, втрата маси.

Помітна втрата маси - непостійний симптом діабету, більш характерний для першого типу захворювання. Особливою відмінністю $є$ схуднення на тлі посиленого харчування дитини або, навіть, «вовчого» апетиту, що теж властиво цукровому діабету. У цьому випадку втрата маси - це наслідок нездатності тканин організму при відсутності інсуліну засвоювати глюкозу. «Голодуючі» тканини просто починають переробляти власні запаси білків та жирів, організм, як би «поїдає» себе зсередини.

Згадані симптоми цукрового діабету в дітей більш характерні для першого типу захворювання. У цьому випадку ознаки діабету розвиваються швидко, іноді стрімко. До того ж юний і дитячий вік $є$ досить характерним для першого типу діабету. Для діабету другого типу характерно тривалий безсимптомний розвиток і повільне наростання симптомів у наступному, тому своєчасна діагностика цього типу діабету є більш складною [4]. Частими скаргами у дітей при цукровому діабеті другого типу є свербіж шкіри, гнійничкові захворювання шкіри, які не чутливі до лікування, часті «заїди», сухість у роті, слабкість у м'язах, постійна 
втома, млявість. На жаль, такі пацієнти, хворі діти частіше звертаються до лікаря не з першими ознаками хвороби, а вже з ускладненнями.

У клінічній картині цукрового діабету першого та другого типів у дітей $є$ певні відмінності. Так, для цукрового діабету першого типу характерними $\epsilon$ підвищена спрага і сечовипускання, відчуття голоду, втрата маси, надмірна втома, дратівливість, фруктовий запах із рота при диханні. Типовими ознаками цукрового діабету другого типу $є$ частіше сечовипускання, особливо вночі, підвищена спрага, втома, безпричинна втрата маси, свербіж навколо статевих органів, іноді пов'язаний з дріжджовою інфекцією, повільне загоєння розрізів або ран, порушення зору, оскільки рогівка стає сухою [6].

Адекватне спостереження за дитиною дозволить своєчасно виявити перші тривожні симптоми і діагностувати захворювання на ранніх стадіях. Своєчасно розпочате лікування допоможе запобігти розвитку ускладнень і підтримувати гарне самопочуття маленького пацієнта.

Лікування цукрового діабету в дітей на початкових етапах необхідно проводити в умовах стаціонару, а далі моніторинг та лікування може здійснюватися амбулаторно, в домашніх умовах. Головною метою терапії цукрового діабету є нормалізація показників ацетонурії, глюкозурії при невеликих дозах інсуліну та чітких дієтичних рекомендаціях, що забезпечить нормальний, повноцінний ріст і розвиток дитини. Дотримання дієтичного харчування $\epsilon$ необхідною умовою адекватного лікування та якості життя маленького чи дорослого пацієнта [7].

Існує величезна кількість найрізноманітніших захворювань, при лікуванні яких велике значення мають не лише рекомендації лікаря, але й сестринський нагляд. Саме цукровий діабет належить до такої патології, яка вимагає особливої відповідальності середнього медичного персоналу щодо ретельного виконання лікарських призначень та відповідного комплаєнсу зі сторони пацієнта [8].

Сестринський нагляд має важливе значення вже на початкових етапах діагностики цукрового діабету в дітей. Медична сестра надає допомогу в зборі даних, необхідних для складання ясної картини про можливі причини розвитку захворювання, бере участь у підготовці маленького пацієнта до лабораторних та інструментальних досліджень, здійснює сестринський догляд під час проведення терапії в умовах стаціонару та вдома [9].
Медична сестра з'ясовує у батьків інформацію про супутні та перенесені захворювання у дитини, про наявність у них або найближчих родичів цукрового діабету, а також про особливості денного розпорядку малюка і його харчування. Водночас медична сестра здійснює огляд шкірних покривів дитини, слизових оболонок, визначає та оцінює показники фізичного розвитку, артеріального тиску. Поряд із цим, середній медичний персонал готує дитину до проведення діагностичних лабораторно-інструментальних тестів, зокрема забір крові та сечі на загально-клінічне дослідження, дослідження крові на наявність глюкози, визначення толерантності до глюкози, рівня інсуліну та глікозильованого гемоглобіну. Високий показник глюкози в крові (вище 5,5 ммоль/л), високий постпрандіальний рівень глюкози (вище 11 ммоль/л), глікозильований гемоглобін свідчать на користь цукрового діабету. Ультразвукове дослідження підшлункової залози у пацієнта дозволить оцінити стан органа і виявити ушкоджені ділянки залози [10].

На сьогодні цукровий діабет вилікувати поки що неможливо, однак це захворювання можна повністю компенсувати, застосовуючи активний спосіб життя дитини, правильне харчування та новітні способи введення інсуліну за допомогою інсулінової помпи, що забезпечує гармонійний розвиток дитини та адекватну якість життя. Для цього вкрай необхідним $\epsilon$ сестринський нагляд як для дітей з цукровим діабетом, так і для їх батьків. Медична сестра допомагає пацієнтові та його батькам дізнатися більше про це захворювання, оволодіти методами самоконтролю рівня глюкози, навичками проведення інсулінотерапії, організації режиму дня та харчування [11].

Висновки. Цукровий діабет все ще залишається серйозним захворюванням із метаболічними розладами та формуванням тяжких ускладнень зураженням серцево-судинної, центральної нервової системи, нирок, прогресуючою втратою зору.

До недавнього часу найпоширенішим типом діабету в дітей і підлітків був перший тип, однак, на сьогодні, зростає поширеність цукрового діабету другого типу серед дітей, особливо з надлишковою масою та ожирінням. Профілактика і лікування цукрового діабету другого типу повинні стати однією з головних цілей програм громадської охорони здоров'я. Набагато більше уваги слід приділяти попередженню і розвитку превентивних стратегій на ранньому етапі життя [12].

Незважаючи на відсутність можливості вилікування цукрового діабету, діти з цим захворюванням можуть 
мати адекватну якість життя, за умови відповідного контролю та моніторингу основних показників. Менеджмент цукрового діабету включає коригуючу інсулінотерапію за допомогою інсулінової помпи або сучасних методів ін'єкційного введення інсулі-

\section{СПИСОК ЛІТЕРАТУРИ}

1. Фадєєв П. О. Цукровий діабет / П. О. Фадєєв. - Тернопіль : Навчальна книга - Богдан, 2011. - 167 с. : табл. (Серія «Енциклопедія медичних знань»).

2. Дитячі хвороби / за ред. В. М. Сидельникова, В. В. Бережного. - К. : Здоров'я, 1999.

3. Сахарный диабет у детей и подростков / И. И. Дедов, Т. Л. Кураева, В. А. Петеркова, Л. Н. Щербачева. - М., 2002.

4. Цукровий діабет у дітей: перебіг і прогноз [Електронний ресурс]. - Режим доступу : <http://ldmp.com.ua/ info/684-cukroviy-dabet-u-dtey-perebg prognoz.html/>. [Cтвор. 2011].

5. Endocrinology Section (Copyright (c) 2014 American Academy of Pediatrics). - URL: <https://www.healthychildren. org/English/health-issues/conditions/chronic/Pages/ Diabetes.aspx/>.[Acc. 2018].

6. Healthline Media UK Ltd, Brighton, UK. - URL : <https:// www.medicalnewstoday.com/articles/284974.php/>.[Acc. 2004]. ну, активний спосіб життя та здорове харчування. Моніторинг та підтримка нормального рівня цукру в крові можуть знизити ризик розвитку віддалених ускладнень, проблем зі здоров'ям, пов'язаних із недостатнім контролем показників цукрового діабету.

7. US National Library of Medicine. - URL : <https:// medlineplus.gov/diabetesinchildrenandteens.html/>.[Acc. 30 June 2016].

8. Secular trends in growth in diabetes: are we winning? / K. C. Donaghue, O. Kordonouri, A Chan, M. Silink // Archives of Disease in Childhood. - 2003.

9. Сестринський процес при цукровому діабеті: для чого він потрібен [Електронний ресурс]. - Режим доступу : $<$ http://likuvan.in.ua/sestrins-kij-protses-pri-tsukrovomudiabeti-dlya-chogo-vin-potriben.html/>.

10. Сестринское дело (c) 2010-2017 [Електронний ресурс]. - Режим доступу : <http://sestrinskoe-delo. ru/sestrinskoe-delo-v-pediatrii/sestrinskiy-protsess-prisacharnom-diabete-u-detey/>.[Созд. 2010].

11. Смолева Э. В. Сестринское дело в терапии / э. В. Смолева. - Ростов-на-Дону : Феникс, 2007.

12. Diabetes.co.uk (c) 2018 Diabetes Digital Media Ltd. URL : <https://www.diabetes.co.uk/children-and-diabetes. html/> .[Acc. 2018]. 